\title{
Steroids, spinal cord and pain sensation
}

\author{
Christine Patte-Mensah, Laurence Meyer and Ayikoe \\ Guy Mensah-Nyagan*
}

Equipe Stéroïdes, Neuromodulateurs et Neuropathologies, Unité de Physiopathologie et Médecine Translationnelle, EA-4438, Université de Strasbourg, Bâtiment 3 de la Faculté de Médecine, 11 rue Humann, Strasbourg, France

\begin{abstract}
During the whole life, the nervous system is continuously submitted to the actions of different categories of hormones, including steroids. Therefore, the interactions between hormonal compounds and neural tissues are subjected to intense investigations. While a majority of studies focus on the brain, the spinal cord (SC) has received little attention, although this structure is also an important part of the central nervous system, controlling motor and sensory functions. To point out the importance of interactions between hormones and the SC in the regulation of neurobiological activities, we recapitulated and discussed herein various key data, revealing that the pivotal role played by the SC in nociception and pain modulation, directly depends on the SC ability to metabolize and synthesize steroidal molecules. The paper suggests that future investigations aiming to develop effective strategies against chronic pain, must integrate regulatory effects exerted by hormonal steroids on the SC activity, as well as the actions of endogenous neurosteroids locally synthesized in spinal neural networks.
\end{abstract}

Keywords: neurosteroid; nociception; pain; spinal cord.

\section{Introduction}

Because of their pleiotropic potential and diverse effects on the central (CNS) and peripheral (PNS) nervous systems, steroids have early been suspected to modulate pain sensation. Indeed, since 1927, Cashin and Moravek observed that intravenous injections of cholesterol were able to suppress pain sensation by exerting anesthetic effects in mammals [1]. Afterwards, Selye demonstrated that certain pregnane steroids, such as progesterone and deoxycorticosterone, can induce sedation and anesthesia in rats [2]. Together, these observations paved the way for the development of various synthetic analogs of pregnane steroids, which reduced pain

*Corresponding author: Ayikoe Guy Mensah-Nyagan, Equipe Stéroïdes, Neuromodulateurs et Neuropathologies, Unité de Physiopathologie et Médecine Translationnelle, EA-4438,

Université de Strasbourg, Bâtiment 3 de la Faculté de Médecine, 11 rue Humann, 67000 Strasbourg, France

Phone: +(33) 3688531 24, Fax: +(33) 3688535 70,

E-mail: gmensah@unistra.fr

Received July 6, 2011; accepted August 2, 2011;

previously published online September 12, 2011 through allosteric activation of $\mathrm{GABA}_{\mathrm{A}}$ receptors [3-7]. Nowadays, the therapeutic use of glucocorticosteroids and their analogs is considered as the most effective strategy against inflammatory pain, in spite of the occurrence of diverse side effects (for reviews, [8, 9]). Glucocorticosteroids reduce inflammatory pain by inducing anti-inflammatory actions on the damaged peripheral or central tissue which activates nociceptive mechanisms and generate pain sensation. The anti-inflammatory effects of glucocorticosteroids result from their ability to inhibit the expression of collagenase (the key enzyme involved in tissue degeneration during inflammatory mechanisms) and pro-inflammatory cytokines, or to stimulate the synthesis of lipocortin, which blocks the production of eicosanoids [10-13]. There is also clinical evidence supporting the use of glucocorticoids in the treatment of chronic neuropathic pain [14-17]. Experimental investigations in animals suggest that glucocorticoids may inhibit the initiation of neuropathic pain states, or attenuate this pain, but the mechanisms of action are unknown [14, 18-21]. It is usually thought that the anti-inflammatory actions of glucocorticosteroids may contribute to the inhibition of the neuroinflammatory component of neuropathic pain, but there is no specific evidence supporting this hypothesis. As an interesting finding revealed that the endoneurial expression of pro-inflammatory cytokines may have a role in the genesis of neuropathic pain, glucocorticosteroids may reduce this pain through the modulation of neuroimmune interactions [22]. In support of this idea, a recent study showed that the glucocorticoid triamcinolone, which reduced the neuropathic pain seen in the model of post-traumatic peripheral neuropathy, also decreased the number of endoneurial mast cells expressing (in the injured nerve) the pro-inflammatory cytokine tumor necrosis factor-alpha [23]. Altogether, the findings recapitulated above, strongly support the existence of key actions of endogenous and synthetic steroids in the modulation of inflammatory and neuropathic pain. The present paper aims to elucidate the specific contribution of steroid and SC interactions in the regulation of nociception and pain.

\section{Background for a pivotal role of steroid and spinal cord interactions in the modulation of pain}

The SC is a target of steroid hormones which are key factors accounting for the gender differences in pain and analgesia (for reviews, [24-28]). Variations in sex steroid levels, receptor expression and mechanisms of action in the nervous system, have been correlated with the development of chronic pain $[24,26]$. Androgens, which are higher in males, exert analgesic effects in humans and experimental models, while estrogens were found to have both hyperalgesic and analgesic effects depending on the experimental conditions 
[28-31]. Moreover, it has recently been shown that progesterone prevents allodynia after SC hemisection-induced injury [32]. In addition to sex steroid-based dimorphism in pain sensation or in the risk of developing pathological pain syndromes, the relationship between opioids and steroid hormones in pain control has also been investigated by different research groups [33-36]. Investigations in humans and animals of the interactions between opioids and sex hormones in pain modulation, suggested that chronic opioid administration without testosterone supplementation may contribute to the perpetuation of chronic pain and to continued administration of unnecessarily high doses of narcotics $[33,34,37$, 38]. Verifications were made with hormonal supplementation in gonadectomized rats and the results indicated that testosterone plays a protective role in pain perception, while estrogens and progesterone mainly act on pain inhibition mechanisms $[39,40]$. Studies focused on the rat SC indicated that sex steroids modulate antinociceptive responses to opioid drugs through the control of the expression of opioid kappa and delta receptors in spinal sensory neurons [41-43]. Progesterone-induced attenuation of pain behaviors in spinally-injured rats was correlated with increased opioid kappa receptor expression and upregulation of NMDA receptor subunits and protein kinase $\mathrm{C}$ gamma [32].

In addition to the effects of hormonal (adrenal and gonadal) steroids on the SC, the local production of endogenous steroids (neurosteroids) has been evidenced in the SC thanks to various investigations that revealed the presence and biological activity of several key steroid-synthesizing enzymes in the rat SC [44-48]. Among these enzymes, are cytochrome P450 side-chain-cleavage (P450scc), cytochrome

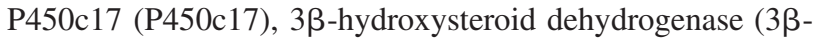
HSD), $5 \alpha$-reductase $(5 \alpha-\mathrm{R})$ and $3 \alpha$-hydroxysteroid oxidoreductase ( $3 \alpha-$ HSOR). P450scc catalyzes the conversion of cholesterol (CHOL) to pregnenolone (PREG), the first and rate-limiting step in the biosynthesis of all classes of steroid hormones. P450c17, also called $17 \alpha$-hydroxylase/17,20 lyase, converts PREG successively into 17-hydroxy-PREG and dehydroepiandrosterone (DHEA). P450c17 is also responsible for the transformation of progesterone (PROG) into 17-hydroxy-PROG and androstenedione, successively. The enzyme $3 \beta-H S D$ catalyzes the conversion of $\Delta^{5}-3 \beta$ hydroxysteroids (PREG, 17-hydroxy-PREG, DHEA) into $\Delta^{4}$-3-ketosteroids (PROG, 17-hydroxy-PROG, androstenedione). $5 \alpha-\mathrm{R}$ is responsible for the transformation of testosterone (T), PROG and deoxycorticosterone (DOC) into dihydrotestosterone (DHT), dihydroprogesterone (DHP) and dihydrodeoxycorticosterone (DHDOC), respectively. $3 \alpha$-HSOR, also called $3 \alpha$-hydroxysteroid dehydrogenase, converts in a reversible manner DHT, DHP and DHDOC into the respective neuroactive steroids $3 \alpha$-androstanediol, allopregnanolone or tetrahydroprogesterone $(3 \alpha, 5 \alpha-\mathrm{THP})$ and tetrahydrodeoxycorticosterone (THDOC).

The first anatomical and cellular distribution of P450scc in the adult rat $\mathrm{SC}$ was provided by immunohistochemical studies, using two different antibodies against P450scc. One of these antisera was raised in rabbits against purified P450scc from bovine adrenocortical mitochondria [49-53].

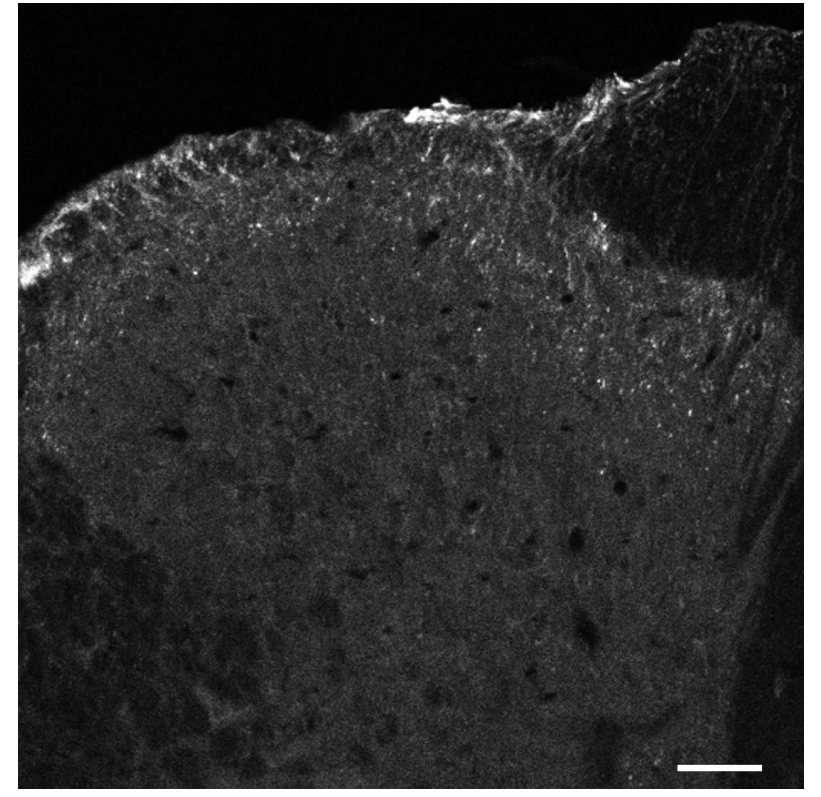

Figure 1 Transverse section through the lumbar SC showing $\mathrm{P} 450$ scc-immunoreactive elements in the superficial layers of the SC dorsal horn (DH). Scale bar: $50 \mu \mathrm{m}$.

The other antiserum was generated in rabbits against the carboxy-terminal aminoacids 509-526 of rat P450scc [54]. The same anatomical and cellular distribution of P450scc-immunoreactivity was observed in the rat $\mathrm{SC}$ with both antisera. The highest density of P450scc-immunolabeling was found in superficial layers laminae I and II of the dorsal horn (DH) where sensory neurons are located (Figure 1). Double-labeling experiments revealed that most of the P450scc-positive fibers in the $\mathrm{DH}$ also expressed immunoreactivity for microtubule-associated protein-2, a specific marker for neuronal fibers [55-57]. Motoneurons of the ventral horn (VH) also expressed immunoreactivity for P450scc, suggesting a possible role of the enzyme or its steroid products in the control of motor activity [55, 58]. Moreover, P450scc-immunostaining was detected in ependymal glial cells bordering the central canal in the SC, an observation which suggests a possible release of neurosteroids in the cerebrospinal fluid and their involvement in volume transmission mechanisms in the CNS $[55,59]$.

Well validated biochemical experiments, which showed that homogenates from the adult rat SC are capable of converting CHOL into PREG, indicated that P450scc-like immunoreactivity detected in the spinal tissue corresponds to an active form of the enzyme [55, 60-64].

The demonstration of the presence and activity of P450c17 in the CNS has long remained controversial (for reviews, $[65,66])$. Therefore, we combined molecular, immunohistochemical and neurochemical approaches for a solid investigation of P450c17 existence and biological activity in adult rodent SC. This multi-technique study allowed the first anatomical and cellular mapping of a biologically active form of P450c17 in the adult rat SC [67]. Significant amounts of P450c17 mRNA were detected in all regions of the SC, using 
the real-time polymerase chain reaction approach after reverse transcription (RT-rtPCR). By taking advantage of the availability of an antibody against P450c17, we revealed the presence of a specific protein in total homogenates and microsomal fractions from the rat $\mathrm{SC}$ and testis. The $\mathrm{P} 450 \mathrm{c} 17$ antiserum used in our studies was also efficient in previous investigations which localized the enzyme in Leydig cells $[68,69]$. This antiserum also allowed the anatomical and cellular localization of $\mathrm{P} 450 \mathrm{c} 17$ throughout the white and gray matters of the SC, using an immunohistochemical approach combined with confocal laser microscope analysis. P450c17-immunostaining was found in both neurons and glial cells. In the white matter, the enzyme was mainly detected in astrocytes, while in the gray matter, P450c17 was essentially found in neurons and oligodendrocytes [67]. The presence of $\mathrm{P} 450 \mathrm{c} 17$ in the $\mathrm{DH}$ and $\mathrm{VH}$ suggested its potential involvement in the modulation of sensory or motor functions [58, 67, 70, 71]. Pulse-chase experiments, which revealed that $\mathrm{SC}$ slices converted $\left[{ }^{3} \mathrm{H}\right] \mathrm{PREG}$ into $\left[{ }^{3} \mathrm{H}\right] \mathrm{DHEA}$, indicated that P450c17-like immunoreactivity detected in the adult rat SC, corresponds to an active form of the enzyme [67]. The occurrence of P450c17 enzymatic activity was further demonstrated with biochemical experiments using ketoconazole, a selective inhibitor of the enzyme [72, 73]. A significant decrease was observed in the conversion of $\left[{ }^{3} \mathrm{H}\right] \mathrm{PREG}$ to $\left[{ }^{3} \mathrm{H}\right] \mathrm{DHEA}$ by $\mathrm{SC}$ slices when the pulse-chase experiments were performed in the presence of ketoconazole, a result which unambiguously confirms the existence of $\mathrm{P} 450 \mathrm{c} 17$ activity in the adult rat SC [67].

The first isolation of $3 \beta$-HSD mRNA in the SC was performed in rats using the RT-PCR approach [74]. However, the anatomical and cellular distribution of $3 \beta$-HSD mRNA in the SC was provided by Coirini et al. [75] utilizing an in situ hybridization technique. This study revealed that the DH laminae I-III exhibited the highest density of $3 \beta-H S D$ mRNAs which were also detected in layer $X$ around the central canal in the $\mathrm{VH}$ and in the lateral as well as ventral funiculi. At the cellular level, 3 $\beta$-HSD mRNAs were found mainly in sensory neurons of the $\mathrm{DH}$ and in motoneurons of the VH throughout the cervical, thoracic, lumbar and sacral segments of the SC [75]. Moreover, evidence for the existence of $3 \beta-\mathrm{HSD}$ protein and enzymatic activity in the SC was provided by Western blot analysis and gas chromatography/mass spectrometry assays, which revealed that the concentrations of PREG and PROG were higher in the SC than in plasma [75]. Recent studies have also confirmed the presence and activity of $3 \beta-\mathrm{HSD}$ in the rat SC by using realtime polymerase chain reaction and pulse-chase experiments, combined with HPLC-Flo/one analysis of steroids newlysynthesized from a radioactive precursor in spinal tissue [76].

The expression of $5 \alpha-\mathrm{R}$ in the brain, but not the SC, has extensively been studied [77-82]. It has been suggested that the isoenzyme $5 \alpha$-R type 1 ( $5 \alpha-\mathrm{R} 1)$ essentially plays a catabolic and neuroprotective role, whereas the isoform 2 or $5 \alpha-\mathrm{R} 2$ participates in sexual differentiation of the CNS. However, the neurophysiological significance of these two isoenzymes remains a matter of speculation [83-86]. The first demonstration of $5 \alpha-\mathrm{R}$ gene expression in the SC was provided by a recent study, which revealed that, unlikely to what is observed in the brain, the quantity of $5 \alpha-\mathrm{R} 2$ mRNAs extracted from the whole adult rat SC is higher than that of $5 \alpha-\mathrm{R} 1$ [87]. This work also indicated that mRNAs encoding $5 \alpha-\mathrm{R} 2$ are expressed by motoneurons of the $\mathrm{VH}$, but did not provide any information about the presence or absence of the enzyme in the $\mathrm{DH}$, where sensory networks are located [70, 71, 88]. Therefore, a detailed immunohistochemical study was performed to determine the regional and cellular distribution of $5 \alpha-\mathrm{R} 1$ and $5 \alpha-\mathrm{R} 2$ in the adult rat SC [89]. The study was possible thanks to the availability of highly specific antisera against $5 \alpha-\mathrm{R} 1$ and $5 \alpha-\mathrm{R} 2$ which were previously used with success to localize these enzymes in various steroidogenic tissues [90, 91]. Immunoreactivities for $5 \alpha-\mathrm{R} 1$ and $5 \alpha-\mathrm{R} 2$ were detected in the white matter of the SC from the cervical to sacral regions. However, the intensity of $5 \alpha-\mathrm{R} 1$-immunostaining was low and cell bodies, as well as fibers containing this isoenzyme, were observed mainly in the white matter of the cervical and thoracic segments. The $5 \alpha-\mathrm{R} 2$ immunofluorescence, which was moderate in the white matter, was intense in the $\mathrm{DH}$ and $\mathrm{VH}$ of the gray matter [89]. Double-labeling identification with specific markers for nerve cells revealed that the $5 \alpha-\mathrm{R} 1$ immunostaining was mainly expressed in oligodendrocytes and astrocytes of the white matter, whereas $5 \alpha$-R2-immunolabeling colocalized with neurons and glial cells in the gray and white matters [56, 57, 89, 92, 93]. The observation of a restricted localization of $5 \alpha-\mathrm{R} 1$ to the $\mathrm{SC}$ white matter is in agreement with previous studies indicating that the type 1 isoform of $5 \alpha-\mathrm{R}$ is the most relevant isoenzyme present in myelinated structures of the female and male rat brain [84, 94-96].

There are four human $3 \alpha$-HSOR isozymes, but, to date, only one isoform has been cloned in rats [97-100]. The enzymatic activity and mRNA encoding $3 \alpha$-HSOR have been detected in the brain, but the immunocytochemical mapping of the protein in the CNS has long remained unexplored [82, 101-103]. Taking advantage of the availability of a specific antiserum against the rat liver $3 \alpha$-HSOR, we determined the anatomical and cellular distribution of the enzyme in the rodent SC (Figure 2). Relative titers, specificity and effectiveness of the $3 \alpha$-HSOR antibody have been shown by previous biochemical and histochemical studies [97-99, 104, 105]. Intense immunoreactivity for $3 \alpha$-HSOR was detected in SC white and gray matters. However, the highest density of $3 \alpha$-HSOR-immunostaining was found in sensory areas of the SC [89]. Our study also revealed that $45 \%$ of $3 \alpha$-HSOR-immunofluorescence was localized in oligodendrocytes, $35 \%$ in neurons and $20 \%$ in astrocytes. A comparative analysis of $5 \alpha-\mathrm{R} 1-, 5 \alpha-\mathrm{R} 2-$ and $3 \alpha$-HSOR-positive elements in the SC, made it possible to observe three different but interesting situations: 1) cell bodies and fibers containing both $3 \alpha$-HSOR and $5 \alpha-\mathrm{R}$ were identified, 2) cells labeled only with the $5 \alpha-\mathrm{R} 1$ or $5 \alpha-\mathrm{R} 2$ antiserum were localized and 3) positive cell bodies expressing only $3 \alpha$-HSORimmunostaining were found [89]. Consequently, it appears that certain glial cells and neurons of the SC contain both $5 \alpha-\mathrm{R}$ and $3 \alpha$-HSOR enzymatic proteins, which could catalyze biochemical reductions required for the biosynthesis of 


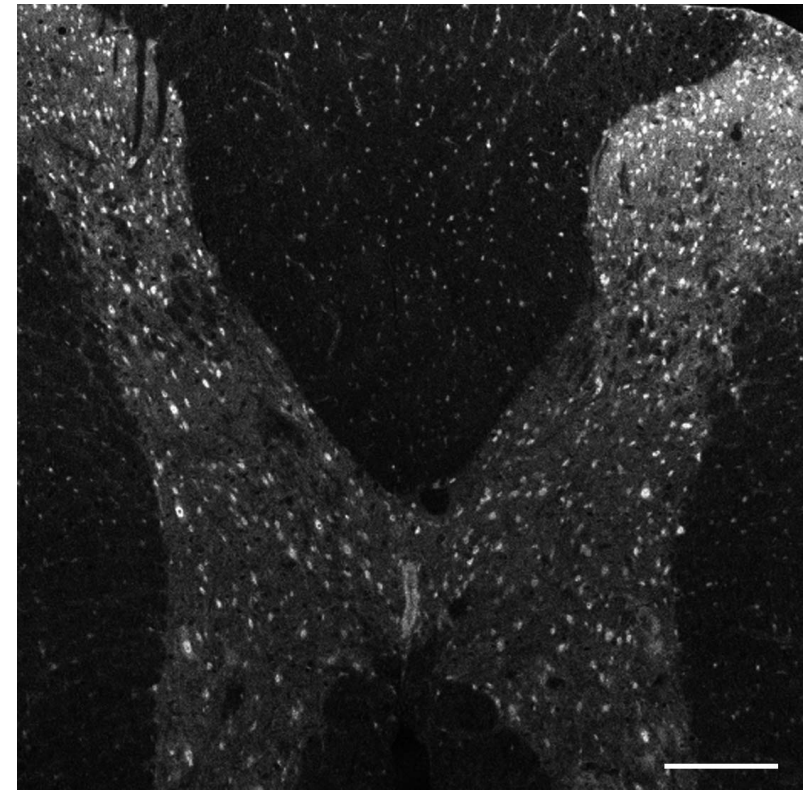

Figure 2 Transverse section through the thoracic SC showing $3 \alpha-$ HSOR-immunoreactive cells and fibers in the white and gray matters. $45 \%$ of $3 \alpha$-HSOR-immunofluorescence was localized in oligodendrocytes, $35 \%$ in neurons and $20 \%$ in astrocytes. Scale bar: $200 \mu \mathrm{m}$.

$3 \alpha, 5 \alpha$-reduced steroids, such as $3 \alpha$-androstanediol, $3 \alpha, 5 \alpha$-THP and THDOC which control, through allosteric modulation of $\mathrm{GABA}_{\mathrm{A}}$ receptors, neurobiological mechanisms including stress, anxiety, analgesia, locomotion and lordosis [6, 106-109]. The production of neuroactive $3 \alpha, 5 \alpha-$ reduced steroids may also involve collaboration among neurons, astrocytes and oligodendrocytes, which contain only one of the two enzymes, i.e., $3 \alpha$-HSOR or $5 \alpha-$ R. This collaboration may be done within the context of the cross-talk between glial and neuronal elements in normal physiological or during pathological situations [110]. These suggestions could not rule out the possibility that $5 \alpha-\mathrm{R} 1$ or $5 \alpha-\mathrm{R} 2$ alone may convert, in the SC, PROG or T from peripheral sources, into DHP or DHT, respectively, that act via genomic receptors, the existence of which has been demonstrated in spinal tissues [111-114]. In a similar manner, $3 \alpha$-HSOR alone may also convert, in the SC, peripheral DHP, DHT or DHDOC into $3 \alpha, 5 \alpha$-THP, $3 \alpha$-androstanediol or THDOC, respectively, for the modulation of $\mathrm{GABA}_{\mathrm{A}}$ receptors $[6,109,115,116]$. The fact that the rat spinal tissue homogenates are capable of converting [ $\left.{ }^{3} \mathrm{H}\right] \mathrm{CHOL}$ into various metabolites, including $3 \alpha, 5 \alpha$-THP, clearly indicates that $5 \alpha-\mathrm{R} 1,5 \alpha-\mathrm{R} 2$ and $3 \alpha-$ HSOR detected in the SC correspond to active forms of these enzymes [55, 89].

\section{Role of spinal neurosteroids in pain regulation}

Neurosteroids modulate $\mathrm{GABA}_{\mathrm{A}}$, NMDA and $\mathrm{P} 2 \mathrm{X}$ receptors which are expressed in the SC and play a crucial role in the regulation of pain $[45,65,71,117]$. However, the local synthesis of neurosteroids near their sites of actions in pain neural centers is a prerequisite to render credible the possible involvement of endogenous neurosteroids in pain modulation. Therefore, the demonstration that the spinal cord, which pivotally controls pain transmission [58, 71, 117], also contains the enzymatic machinery to locally synthesize neurosteroids (see above) was extremely important to show that neurosteroids are produced and released near their sites of actions in the spinal pain circuit. In addition, we observed that substance P, a major nociceptive neuropeptide secreted by primary afferents, inhibited in a dose-dependent manner allopregnanolone $(3 \alpha, 5 \alpha$-THP) biosynthesis in the DH [118]. As the neurosteroid $3 \alpha, 5 \alpha$-THP is a potent allosteric stimulator of $\mathrm{GABA}_{\mathrm{A}}$ receptors, our observation suggested that substance $\mathrm{P}$, by reducing $3 \alpha, 5 \alpha$-THP production, may indirectly decrease the spinal inhibitory tone and therefore facilitate noxious signal transmission.

To further investigate the possible role of neurosteroids endogenously produced in the SC in pain modulation, we performed a multidisciplinary study using the rat experimental model of neuropathic pain generated by sciatic nerve ligatures [119]. Molecular and biochemical investigations (quantitative real time polymerase chain reaction after reverse transcription, Western blot, radioimmunoassay, pulse-chase experiments, high performance liquid chromatography and continuous flow scintillation detection) revealed an up-regulation of enzymatic pathways (P450scc and $3 \alpha$-HSOR) leading to $3 \alpha, 5 \alpha$-THP biosynthesis in the SC [89, 120, 121]. In contrast, the biosynthetic pathway (P450c17) producing DHEA was down-regulated in the neuropathic rat SC $[67,122]$. Behavioral studies using the plantar test (thermal nociceptive threshold) and the von Frey filament test (mechanical nociceptive threshold) showed that intrathecal administration of $3 \alpha, 5 \alpha-$ THP in the lumbar SC induced analgesia in neuropathic-pain rats, by suppressing the thermal hyperalgesia and mechanical allodynia characterizing these animals. Unlike $3 \alpha, 5 \alpha$-THP, intrathecal injection of Provera $(3 \alpha-\mathrm{HSOR}$ inhibitor) potentiated both thermal hyperalgesia and mechanical allodynia in neuropathic rats [121]. Moreover, in vivo knockdown of $3 \alpha$-HSOR expression in healthy rat lumbar dorsal root ganglia using 6carboxyfluorescein- $3 \alpha$-HSOR-siRNA, exacerbated thermal and mechanical pain perception [123].

Acute DHEA treatment exerted a rapid pro-nociceptive and a delayed anti-nociceptive action. Inhibition of DHEA biosynthesis in the DH by intrathecally administered ketoconazole (a P450c17 inhibitor) induced analgesia in neuropathic rats. Chronic treatment of DHEA increased and maintained elevated basal pain thresholds in neuropathic and control rats, suggesting that androgenic metabolites, generated from daily injected DHEA, exerted analgesic effects while DHEA itself (before being metabolized) induced a rapid pro-nociceptive action [122].

In agreement with our findings showing spinal neurosteroid involvement in pain modulation, various other investigations using synthetic analogs of $3 \alpha, 5 \alpha$-THP also revealed antinociceptive properties of neurosteroids in humans and 
animals [124-128]. Furthermore, it has clearly been demonstrated that $5 \alpha$-reduced neurosteroids induce a potent peripheral analgesia which is mediated by both T-type calcium and $\mathrm{GABA}_{\mathrm{A}}$ channels [129].

\section{Conclusion}

Pain, the first reason for medical consultation in many diseases, is a complex process involving several molecular, cellular and integrated mechanisms as well as psychosocial parameters. The data reviewed herein demonstrate that the interactions between steroids (hormonal steroids and spinal neurosteroids) crucially regulate diverse processes determining the sensitivity to pain. The paper suggests that the investigations aiming to develop effective strategies against chronic pain may particularly integrate the pivotal role played by spinal endogenous neurosteroids in the control of nociceptive transmission.

\section{References}

1. Cashin M, Moravek V. The physiological action of cholesterol. Am J Physiol 1927;82:294-8.

2. Selye H, Masson G. Additional steroids with luteoid activity. Science 1942;96:358.

3. Kraulis I, Foldes G, Traikov H, Dubrovsky B, Birmingham. Distribution, metabolism and biological activity of deoxycorticosterone in the central nervous system. Brain Res 1975;88: $1-14$.

4. Holzbauer M. Proceedings: physiological aspects of the hypnotic properties of steroid hormones. Br J Pharmacol 1976;56: 382P-P.

5. Purdy RH, Morrow AL, Moore PH, Jr., Paul SM. Stressinduced elevations of gamma-aminobutyric acid type A receptor-active steroids in the rat brain. Proc Natl Acad Sci USA 1991;88:4553-7.

6. Majewska MD. Neurosteroids: endogenous bimodal modulators of the GABAA receptor. Mechanism of action and physiological significance. Prog Neurobiol 1992;38:379-95.

7. Belelli D, Lambert JJ. Neurosteroids: endogenous regulators of the GABA(A) receptor. Nat Rev Neurosci 2005;6:565-75.

8. Barnes PJ. Anti-inflammatory actions of glucocorticoids: molecular mechanisms. Clin Sci (Lond) 1998;94:557-72.

9. Belvisi MG, Hele DJ. Soft steroids: a new approach to the treatment of inflammatory airways diseases. Pulm Pharmacol Ther 2003;16:321-5.

10. Firestein GS, Paine MM, Littman BH. Gene expression (collagenase, tissue inhibitor of metalloproteinases, complement, and HLA-DR) in rheumatoid arthritis and osteoarthritis synovium. Quantitative analysis and effect of intraarticular corticosteroids. Arthritis Rheum 1991;34:1094-105.

11. Barnes PJ, Adcock I. Anti-inflammatory actions of steroids: molecular mechanisms. Trends Pharmacol Sci 1993;14:436-41.

12. Fakih M, Johnson CS, Trump DL. Glucocorticoids and treatment of prostate cancer: a preclinical and clinical review. Urology 2002;60:553-61.
13. Sibilia J. Corticosteroids and inflammation. Rev Prat 2003; 53:495-501.

14. Devor M, Govrin-Lippmann R, Raber P. Corticosteroids suppress ectopic neural discharge originating in experimental neuromas. Pain 1985;22:127-37.

15. Kingery WS. A critical review of controlled clinical trials for peripheral neuropathic pain and complex regional pain syndromes. Pain 1997;73:123-39.

16. Lussier D, Huskey AG, Portenoy RK. Adjuvant analgesics in cancer pain management. Oncologist 2004;9:571-91.

17. Wareham D. Postherpetic neuralgia. Clin Evid 2004;12: 1182-93.

18. Clatworthy AL, Illich PA, Castro GA, Walters ET. Role of periaxonal inflammation in the development of thermal hyperalgesia and guarding behavior in a rat model of neuropathic pain. Neurosci Lett 1995;184:5-8.

19. Johansson A, Bennett GJ. Effect of local methylprednisolone on pain in a nerve injury model. A pilot study. Reg Anesth 1997;22:59-65.

20. Kingery WS, Castellote JM, Maze M. Methylprednisolone prevents the development of autotomy and neuropathic edema in rats, but has no effect on nociceptive thresholds. Pain 1999; 80:555-66.

21. Takeda K, Sawamura S, Sekiyama H, Tamai H, Hanaoka K. Effect of methylprednisolone on neuropathic pain and spinal glial activation in rats. Anesthesiology 2004;100:1249-57.

22. Sommer C, Kress M. Recent findings on how proinflammatory cytokines cause pain: peripheral mechanisms in inflammatory and neuropathic hyperalgesia. Neurosci Lett 2004;361:184-7.

23. Hayashi R, Xiao W, Kawamoto M, Yuge O, Bennett GJ. Systemic glucocorticoid therapy reduces pain and the number of endoneurial tumor necrosis factor-alpha (TNFalpha)-positive mast cells in rats with a painful peripheral neuropathy. J Pharmacol Sci 2008;106:559-65.

24. Aloisi AM. Gonadal hormones and sex differences in pain reactivity. Clin J Pain 2003;19:168-74.

25. Arendt-Nielsen L, Bajaj P, Drewes AM. Visceral pain: gender differences in response to experimental and clinical pain. Eur J Pain 2004;8:465-72.

26. Craft RM, Mogil JS, Aloisi AM. Sex differences in pain and analgesia: the role of gonadal hormones. Eur J Pain 2004;8: 397-411.

27. Fillingim RB, Gear RW. Sex differences in opioid analgesia: clinical and experimental findings. Eur J Pain 2004;8:413-25.

28. Aloisi AM, Bonifazi M. Sex hormones, central nervous system and pain. Horm Behav 2006;50:1-7.

29. Ceccarelli I, Fiorenzani P, Massafra C, Aloisi AM. Long-term ovariectomy changes formalin-induced licking in female rats: the role of estrogens. Reprod Biol Endocrinol 2003;1:24.

30. Aloisi AM, Ceccarelli I, Fiorenzani P, De Padova AM, Massafra C. Testosterone affects formalin-induced responses differently in male and female rats. Neurosci Lett 2004;361:262-4.

31. Hau M, Dominguez OA, Evrard HC. Testosterone reduces responsiveness to nociceptive stimuli in a wild bird. Horm Behav 2004;46:165-70.

32. Coronel MF, Labombarda F, Villar MJ, De Nicola AF, Gonzalez SL. Progesterone prevents allodynia after experimental spinal cord injury. J Pain 2011;12:71-83.

33. Aloisi AM, Pari G, Ceccarelli I, Vecchi I, Ietta F, et al. Genderrelated effects of chronic non-malignant pain and opioid therapy on plasma levels of macrophage migration inhibitory factor (MIF). Pain 2005;115:142-51.

34. Ceccarelli I, Fiorenzani P, Massafra C, Aloisi AM. Repeated 
nociceptive stimulation induces different behavioral and neuronal responses in intact and gonadectomized female rats. Brain Res 2006;1106:142-9.

35. Gear RW, Miaskowski C, Gordon NC, Paul SM, Heller PH, et al. Kappa-opioids produce significantly greater analgesia in women than in men. Nat Med 1996;2:1248-50.

36. Gear RW, Miaskowski C, Gordon NC, Paul SM, Heller PH, et al. The kappa opioid nalbuphine produces gender- and dosedependent analgesia and antianalgesia in patients with postoperative pain. Pain 1999;83:339-45.

37. Abs R, Verhelst J, Maeyaert J, Van Buyten JP, Opsomer F, et al. Endocrine consequences of long-term intrathecal administration of opioids. J Clin Endocrinol Metab 2000;85:2215-22.

38. Roberts LJ, Finch PM, Pullan PT, Bhagat CI, Price LM. Sex hormone suppression by intrathecal opioids: a prospective study. Clin J Pain 2002;18:144-8.

39. Gaumond I, Arsenault P, Marchand S. Specificity of female and male sex hormones on excitatory and inhibitory phases of formalin-induced nociceptive responses. Brain Res 2005;1052: $105-11$

40. Gaumond I, Spooner MF, Marchand S. Sex differences in opioid-mediated pain inhibitory mechanisms during the interphase in the formalin test. Neuroscience 2007;146:366-74.

41. Dawson-Basoa M, Gintzler AR. Estrogen and progesterone activate spinal kappa-opiate receptor analgesic mechanisms. Pain 1996;64:608-15.

42. Dawson-Basoa M, Gintzler AR. Gestational and ovarian sex steroid antinociception: synergy between spinal kappa and delta opioid systems. Brain Res 1998;794:61-7.

43. Liu NJ, Gintzler AR. Prolonged ovarian sex steroid treatment of male rats produces antinociception: identification of sex-based divergent analgesic mechanisms. Pain 2000;85: 273-81

44. Melcangi RC, Garcia-Segura LM, Mensah-Nyagan AG. Neuroactive steroids: state of the art and new perspectives. Cell Mol Life Sci 2008;65:777-97.

45. Mensah-Nyagan AG, Kibaly C, Schaeffer V, Venard C, Meyer L, et al. Endogenous steroid production in the spinal cord and potential involvement in neuropathic pain modulation. J Steroid Biochem Mol Biol 2008;109:286-93.

46. Patte-Mensah C, Kibaly C, Boudard D, Schaeffer V, Begle A, et al. Neurogenic pain and steroid synthesis in the spinal cord. J Mol Neurosci 2006;28:17-31.

47. Patte-Mensah C, Mensah-Nyagan AG. Peripheral neuropathy and neurosteroid formation in the central nervous system. Brain Res Rev 2008;57:454-9.

48. Schaeffer V, Meyer L, Patte-Mensah C, Mensah-Nyagan AG. Progress in dorsal root ganglion neurosteroidogenic activity: basic evidence and pathophysiological correlation. Prog Neurobiol 2010;92:33-41.

49. Suhara K, Gomi T, Sato H, Itagaki E, Takemori S, et al. Purification and immunochemical characterization of the two adrenal cortex mitochondrial cytochrome P-450-proteins. Arch Biochem Biophys 1978;190:290-9.

50. Ikushiro S, Kominami S, Takemori S. Adrenal P-450scc modulates activity of P-45011 beta in liposomal and mitochondrial membranes. Implication of P-450scc in zone specificity of aldosterone biosynthesis in bovine adrenal. J Biol Chem 1992;267:1464-9.

51. Tsutsui K, Yamazaki T. Avian neurosteroids. I. Pregnenolone biosynthesis in the quail brain. Brain Res 1995;678:1-9.

52. Usui M, Yamazaki T, Kominami S, Tsutsui K. Avian neurosteroids. II. Localization of a cytochrome P450scc-like substance in the quail brain. Brain Res 1995;678:10-20.
53. Ukena K, Usui M, Kohchi C, Tsutsui K. Cytochrome P450 side-chain cleavage enzyme in the cerebellar Purkinje neuron and its neonatal change in rats. Endocrinology 1998;139: 137-47.

54. Roby KF, Larsen D, Deb S, Soares MJ. Generation and characterization of antipeptide antibodies to rat cytochrome P-450 side-chain cleavage enzyme. Mol Cell Endocrinol 1991;79: 13-20.

55. Patte-Mensah C, Kappes V, Freund-Mercier MJ, Tsutsui K, Mensah-Nyagan AG. Cellular distribution and bioactivity of the key steroidogenic enzyme, cytochrome P450side chain cleavage, in sensory neural pathways. J Neurochem 2003;86: 1233-46.

56. Kennedy PG. Neural cell markers and their applications to neurology. J Neuroimmunol 1982;2:35-53.

57. Nagle RB. Intermediate filaments: a review of the basic biology. Am J Surg Pathol 1988;12: Suppl 1:4-16.

58. Haines DE, Mihailoff GA, Yezierski RP. The spinal cord. In: Haines DE, editor. Fundamental neuroscience. New York: Churchill Livingstone Inc., 1997:129-41.

59. Fuxe K, Agnati LF, editors. Volume transmission in the brain: novel mechanisms for neuronal transmission. New York: Raven, 1992.

60. Mensah-Nyagan AG, Feuilloley M, Dupont E, Do-Rego JL, Leboulenger F, et al. Immunocytochemical localization and biological activity of 3 beta-hydroxysteroid dehydrogenase in the central nervous system of the frog. J Neurosci 1994;14: 7306-18

61. Mensah-Nyagan AG, Do-Rego JL, Feuilloley M, Marcual A, Lange $\mathrm{C}$, et al. In vivo and in vitro evidence for the biosynthesis of testosterone in the telencephalon of the female frog. $\mathrm{J}$ Neurochem 1996;67:413-22.

62. Mensah-Nyagan AG, Feuilloley M, Do-Rego JL, Marcual A, Lange C, et al. Localization of 17beta-hydroxysteroid dehydrogenase and characterization of testosterone in the brain of the male frog. Proc Natl Acad Sci USA 1996;93:1423-8.

63. Mensah-Nyagan AG, Do-Rego JL, Beaujean D, Luu-The V, Pelletier G, et al. Regulation of neurosteroid biosynthesis in the frog diencephalon by GABA and endozepines. Horm Behav 2001;40:218-25.

64. Mensah-Nyagan AG, Beaujean D, Luu-The V, Pelletier G, Vaudry $\mathrm{H}$. Anatomical and biochemical evidence for the synthesis of unconjugated and sulfated neurosteroids in amphibians. Brain Res Brain Res Rev 2001;37:13-24.

65. Baulieu EE, Robel P, Schumacher M, editors. Contemporary endocrinology. Totowa: Humana Press, 1999.

66. Mensah-Nyagan AG, Do-Rego JL, Beaujean D, Luu-The V, Pelletier G, et al. Neurosteroids: expression of steroidogenic enzymes and regulation of steroid biosynthesis in the central nervous system. Pharmacol Rev 1999;51:63-81.

67. Kibaly C, Patte-Mensah C, Mensah-Nyagan AG. Molecular and neurochemical evidence for the biosynthesis of dehydroepiandrosterone in the adult rat spinal cord. J Neurochem 2005;93: 1220-30.

68. Hales DB. Interleukin-1 inhibits Leydig cell steroidogenesis primarily by decreasing 17 alpha-hydroxylase/C17-20 lyase cytochrome P450 expression. Endocrinology 1992;131:216572.

69. Hales DB, Sha LL, Payne AH. Testosterone inhibits cAMP-induced de Novo synthesis of Leydig cell cytochrome P-450(17 alpha) by an androgen receptor-mediated mechanism. J Biol Chem 1987;262:11200-6.

70. Willis WD, Westlund KN, Carlton SM. Pain. In: Paxinos G, editor. The rat nervous system, 2nd edn. Sydney: Academic Press Inc., 1995:725-50. 
71. Millan MJ. The induction of pain: an integrative review. Prog Neurobiol 1999;57:1-164.

72. Kuhn-Velten WN, Lessmann M. Ketoconazole inhibition of the bifunctional cytochrome P450c17 does not affect androgen formation from the endogenous lyase substrate. The catalytic site remains refractory in the course of intermediary hydroxyprogesterone processing. Biochem Pharmacol 1992;44:2371-8.

73. Swart P, Swart AC, Waterman MR, Estabrook RW, Mason JI. Progesterone 16 alpha-hydroxylase activity is catalyzed by human cytochrome P450 17 alpha-hydroxylase. J Clin Endocrinol Metab 1993;77:98-102.

74. Sanne JL, Krueger KE. Expression of cytochrome P450 sidechain cleavage enzyme and 3 beta-hydroxysteroid dehydrogenase in the rat central nervous system: a study by polymerase chain reaction and in situ hybridization. J Neurochem 1995; 65:528-36.

75. Coirini H, Gouezou M, Liere P, Delespierre B, Pianos A, et al. 3 Beta-hydroxysteroid dehydrogenase expression in rat spinal cord. Neuroscience 2002;113:883-91.

76. Saredi S, Patte-Mensah C, Melcangi RC, Mensah-Nyagan AG. Effect of streptozotocin-induced diabetes on the gene expression and biological activity of 3beta-hydroxysteroid dehydrogenase in the rat spinal cord. Neuroscience 2005;135:869-77.

77. Saitoh H, Hirato K, Yanaihara T, Nakayama T. A study of 5 alpha-reductase in human fetal brain. Endocrinol Jpn 1982; 29:461-7.

78. Melcangi RC, Celotti F, Castano P, Martini L. Differential localization of the 5 alpha-reductase and the 3 alpha-hydroxysteroid dehydrogenase in neuronal and glial cultures. Endocrinology 1993;132:1252-9.

79. Pelletier G, Luu-The V, Labrie F. Immunocytochemical localization of 5 alpha-reductase in rat brain. Mol Cell Neurosci 1994;5:394-9.

80. Martini L, Celotti F, Melcangi RC. Testosterone and progesterone metabolism in the central nervous system: cellular localization and mechanism of control of the enzymes involved. Cell Mol Neurobiol 1996;16:271-82.

81. Negri-Cesi P, Poletti A, Celotti F. Metabolism of steroids in the brain: a new insight into the role of 5alpha-reductase and aromatase in brain differentiation and functions. J Steroid Biochem Mol Biol 1996;58:455-66.

82. Stoffel-Wagner B, Watzka M, Steckelbroeck S, Ludwig M, Clusmann $\mathrm{H}$, et al. Allopregnanolone serum levels and expression of 5 alpha-reductase and 3 alpha-hydroxysteroid dehydrogenase isoforms in hippocampal and temporal cortex of patients with epilepsy. Epilepsy Res 2003;54:11-9.

83. Celotti F, Melcangi RC, Martini L. The 5 alpha-reductase in the brain: molecular aspects and relation to brain function. Front Neuroendocrinol 1992;13:163-215.

84. Poletti A, Coscarella A, Negri-Cesi P, Colciago A, Celotti F, et al. 5 alpha-reductase isozymes in the central nervous system. Steroids 1998;63:246-51.

85. Poletti A, Negri-Cesi P, Rabuffetti M, Colciago A, Celotti F, et al. Transient expression of the 5alpha-reductase type 2 isozyme in the rat brain in late fetal and early postnatal life. Endocrinology 1998;139:2171-8.

86. Torres JM, Ortega E. Differential regulation of steroid 5alphareductase isozymes expression by androgens in the adult rat brain. Faseb J 2003;17:1428-33.

87. Pozzi P, Bendotti C, Simeoni S, Piccioni F, Guerini V, et al. Androgen 5-alpha-reductase type 2 is highly expressed and active in rat spinal cord motor neurones. J Neuroendocrinol 2003;15:882-7.
88. Julius D, Basbaum AI. Molecular mechanisms of nociception. Nature 2001;413:203-10.

89. Patte-Mensah C, Penning TM, Mensah-Nyagan AG. Anatomical and cellular localization of neuroactive 5 alpha/ 3 alphareduced steroid-synthesizing enzymes in the spinal cord. J Comp Neurol 2004;477:286-99.

90. Andersson S, Russell DW. Structural and biochemical properties of cloned and expressed human and rat steroid 5 alphareductases. Proc Natl Acad Sci USA 1990;87:3640-4.

91. Thigpen AE, Cala KM, Russell DW. Characterization of Chinese hamster ovary cell lines expressing human steroid 5 alpha-reductase isozymes. J Biol Chem 1993;268:17404-12.

92. Raff MC, Mirsky R, Fields KL, Lisak RP, Dorfman SH, et al. Galactocerebroside is a specific cell-surface antigenic marker for oligodendrocytes in culture. Nature 1978;274:813-6.

93. Matus A. Microtubule-associated proteins. Curr Opin Cell Biol 1990;2:10-4.

94. Melcangi RC, Celotti F, Ballabio M, Castano P, Poletti A, et al. Ontogenetic development of the 5 alpha-reductase in the rat brain: cerebral cortex, hypothalamus, purified myelin and isolated oligodendrocytes. Brain Res Dev Brain Res 1988;44:181-8.

95. Melcangi RC, Celotti F, Ballabio M, Poletti A, Castano P, et al. Testosterone 5 alpha-reductase activity in the rat brain is highly concentrated in white matter structures and in purified myelin sheaths of axons. J Steroid Biochem 1988;31: 173-9.

96. Poletti A, Celotti F, Rumio C, Rabuffetti M, Martini L. Identification of type 1 5alpha-reductase in myelin membranes of male and female rat brain. Mol Cell Endocrinol 1997;129: 181-90.

97. Pawlowski JE, Huizinga M, Penning TM. Cloning and sequencing of the cDNA for rat liver 3 alpha-hydroxysteroid/ dihydrodiol dehydrogenase. J Biol Chem 1991;266:8820-5.

98. Jez JM, Bennett MJ, Schlegel BP, Lewis M, Penning TM. Comparative anatomy of the aldo-keto reductase superfamily. Biochem J 1997;326(Pt 3):625-36.

99. Jez JM, Flynn TG, Penning TM. A new nomenclature for the aldo-keto reductase superfamily. Biochem Pharmacol 1997;54:639-47.

100. Penning TM, Jin Y, Heredia VV, Lewis M. Structure-function relationships in 3alpha-hydroxysteroid dehydrogenases: a comparison of the rat and human isoforms. J Steroid Biochem Mol Biol 2003;85:247-55.

101. Krieger NR, Scott RG. 3 alpha-Hydroxysteroid oxidoreductase in rat brain. J Neurochem 1984;42:887-90.

102. Krieger NR, Scott RG. Nonneuronal localization for steroid converting enzyme: 3 alpha-hydroxysteroid oxidoreductase in olfactory tubercle of rat brain. J Neurochem 1989;52: 1866-70.

103. Khanna M, Qin KN, Cheng KC. Distribution of 3 alphahydroxysteroid dehydrogenase in rat brain and molecular cloning of multiple cDNAs encoding structurally related proteins in humans. J Steroid Biochem Mol Biol 1995;53:41-6.

104. Smithgall TE, Penning TM. Electrophoretic and immunochemical characterization of 3 alpha-hydroxysteroid/dihydrodiol dehydrogenases of rat tissues. Biochem J 1988;254:715-21.

105. Jez JM, Schlegel BP, Penning TM. Characterization of the substrate binding site in rat liver 3alpha-hydroxysteroid/dihydrodiol dehydrogenase. The roles of tryptophans in ligand binding and protein fluorescence. J Biol Chem 1996;271: 30190-8. 
106. Paul SM, Purdy RH. Neuroactive steroids. Faseb J 1992; 6:2311-22.

107. Frye CA, Duncan JE, Basham M, Erskine MS. Behavioral effects of 3 alpha-androstanediol. II: hypothalamic and preoptic area actions via a GABAergic mechanism. Behav Brain Res 1996;79:119-30.

108. Frye CA, Rhodes ME, Rosellini R, Svare B. The nucleus accumbens as a site of action for rewarding properties of testosterone and its 5alpha-reduced metabolites. Pharmacol Biochem Behav 2002;74:119-27.

109. Reddy DS. Is there a physiological role for the neurosteroid THDOC in stress-sensitive conditions? Trends Pharmacol Sci 2003;24:103-6.

110. Melcangi RC, Poletti A, Cavarretta I, Celotti F, Colciago A, et al. The 5alpha-reductase in the central nervous system: expression and modes of control. J Steroid Biochem Mol Biol 1998;65:295-9.

111. Lumbroso S, Sandillon F, Georget V, Lobaccaro JM, Brinkmann AO, et al. Immunohistochemical localization and immunoblotting of androgen receptor in spinal neurons of male and female rats. Eur J Endocrinol 1996;134:626-32.

112. Matsumoto A. Hormonally induced neuronal plasticity in the adult motoneurons. Brain Res Bull 1997;44:539-47.

113. Kastrup Y, Hallbeck M, Amandusson A, Hirata S, Hermanson $\mathrm{O}$, et al. Progesterone receptor expression in the brainstem of the female rat. Neurosci Lett 1999;275:85-8.

114. Labombarda F, Guennoun R, Gonzalez S, Roig P, Lima A, et al. Immunocytochemical evidence for a progesterone receptor in neurons and glial cells of the rat spinal cord. Neurosci Lett 2000;288:29-32.

115. Frye CA. The role of neurosteroids and non-genomic effects of progestins and androgens in mediating sexual receptivity of rodents. Brain Res Brain Res Rev 2001;37:201-22.

116. Lambert JJ, Belelli D, Peden DR, Vardy AW, Peters JA. Neurosteroid modulation of GABAA receptors. Prog Neurobiol 2003;71:67-80.

117. Millan MJ. Descending control of pain. Prog Neurobiol 2002;66:355-474.

118. Patte-Mensah C, Kibaly C, Mensah-Nyagan AG. Substance P inhibits progesterone conversion to neuroactive metabolites in spinal sensory circuit: a potential component of nociception. Proc Natl Acad Sci USA 2005;102:9044-9.

119. Bennett GJ, Xie YK. A peripheral mononeuropathy in rat that produces disorders of pain sensation like those seen in man. Pain 1988;33:87-107.

120. Patte-Mensah C, Li S, Mensah-Nyagan AG. Impact of neuropathic pain on the gene expression and activity of cytochrome P450side-chain-cleavage in sensory neural networks. Cell Mol Life Sci 2004;61:2274-84.

121. Meyer L, Venard C, Schaeffer V, Patte-Mensah C, MensahNyagan AG. The biological activity of 3alpha-hydroxysteroid oxido-reductase in the spinal cord regulates thermal and mechanical pain thresholds after sciatic nerve injury. Neurobiol Dis 2008;30:30-41.

122. Kibaly C, Meyer L, Patte-Mensah C, Mensah-Nyagan AG. Biochemical and functional evidence for the control of pain mechanisms by dehydroepiandrosterone endogenously synthesized in the spinal cord. Faseb J 2008;22:93-104.

123. Patte-Mensah C, Meyer L, Schaeffer V, Mensah-Nyagan AG. Selective regulation of 3 alpha-hydroxysteroid oxido-reductase expression in dorsal root ganglion neurons: a possible mechanism to cope with peripheral nerve injury-induced chronic pain. Pain 2010;150:522-34.

124. Goodchild CS, Guo Z, Nadeson R. Antinociceptive properties of neurosteroids I. Spinally-mediated antinociceptive effects of water-soluble aminosteroids. Pain 2000;88:23-9.

125. Goodchild CS, Robinson A, Nadeson R. Antinociceptive properties of neurosteroids IV: pilot study demonstrating the analgesic effects of alphadolone administered orally to humans. Br J Anaesth 2001;86:528-34.

126. Nadeson R, Goodchild CS. Antinociceptive properties of neurosteroids II. Experiments with Saffan and its components alphaxalone and alphadolone to reveal separation of anaesthetic and antinociceptive effects and the involvement of spinal cord GABA(A) receptors. Pain 2000;88:31-9.

127. Nadeson R, Goodchild CS. Antinociceptive properties of neurosteroids III: experiments with alphadolone given intravenously, intraperitoneally, and intragastrically. $\mathrm{Br} \mathrm{J}$ Anaesth 2001;86:704-8.

128. Gambhir M, Mediratta PK, Sharma KK. Evaluation of the analgesic effect of neurosteroids and their possible mechanism of action. Indian J Physiol Pharmacol 2002;46:202-8.

129. Pathirathna S, Brimelow BC, Jagodic MM, Krishnan K, Jiang $X$, et al. New evidence that both T-type calcium channels and GABAA channels are responsible for the potent peripheral analgesic effects of 5alpha-reduced neuroactive steroids. Pain 2005;114:429-43. 